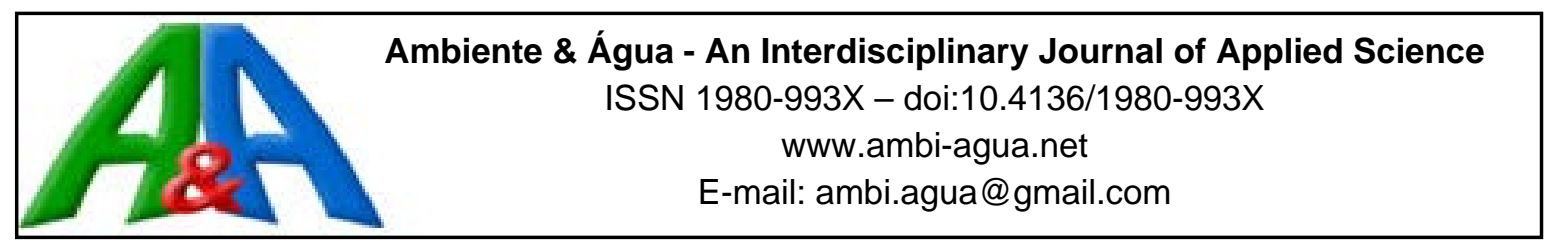

\title{
Coal extraction causes sediment toxicity in aquatic environments in Santa Catarina, Brazil
}

\author{
doi:10.4136/ambi-agua.2036
}

Received: 31 Oct. 2016; Accepted: 10 May 2017

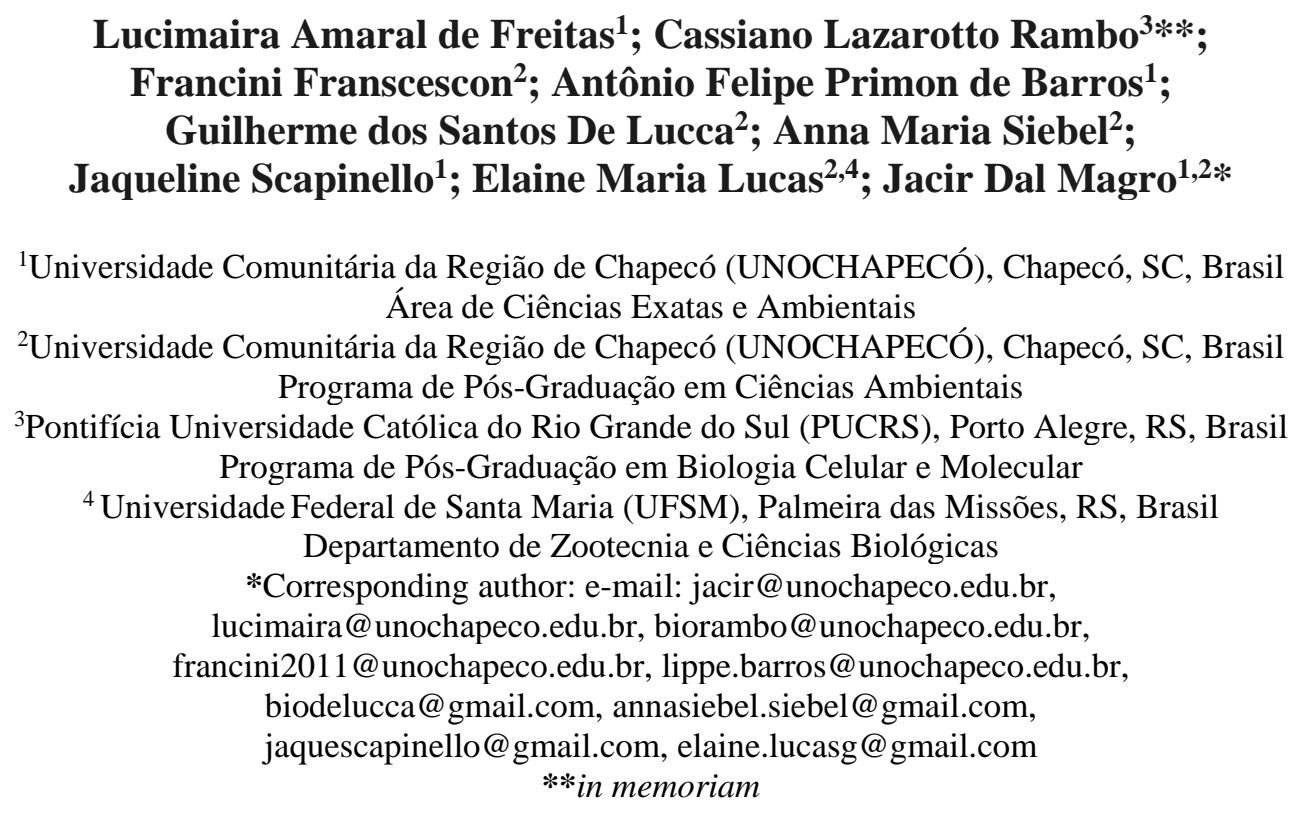

\section{ABSTRACT}

This study evaluated water parameters in ponds affected by coal extraction. Allium cepa assay was used to measure genotoxicity/mutagenicity of the sediment. Samples were collected from four ponds in the southern state of Santa Catarina. Water temperature, $\mathrm{pH}$, dissolved oxygen, conductivity and turbidity were measured. Sediments were analyzed for heavy metals. Elutriate samples were prepared at a ratio of 1:4 sediment:water. Allium cepa bulbs were placed in samples prepared from each pond, with ultrapure water used as negative control and methyl methane sulfonate as positive control. Root length, mitotic index, chromosomal aberrations, micronuclei, and nuclear abnormalities were measured. The $\mathrm{pH}$ of two ponds, as well as electrical conductivity and dissolved oxygen of all ponds were below the minimum limits set by Brazilian regulation. All heavy metals analyzed were found in all sediment samples, but only Cd concentration was above the legal limit set by Brazilian law. Allium cepa root growth for samples from Ponds 1, 2, and 4 was significantly lower than the negative control. Meristematic cells exposed to elutriate samples showed no significant changes in cell division. There was a significant increase in total chromosomal aberrations in all treated samples in comparison with the negative control. This study demonstrates that even low concentrations of heavy metals can damage exposed biota, possibly due to synergistic effects. We also found the $A$. cepa bioassay to be a simple and useful tool for genotoxicity/mutagenicity analyses, and recommend its use for environmental monitoring and management in areas influenced by mining activities.

Keywords: cell damage, genotoxic damage, toxic metals. 


\section{Toxicidade de sedimentos em ambientes aquáticos com influência da extração de carvão no sul de Santa Catarina, Brasil}

\section{RESUMO}

Este estudo analisou parâmetros de qualidade da água em lagoas sob influência de extração de carvão na região sul do estado de Santa Catarina. A genotoxicidade/mutagenicidade de sedimentos foram analisadas usando-se o ensaio Allium cepa. A temperatura, $\mathrm{pH}$, oxigênio dissolvido, condutividade e turbidez foram mensuradas em sete lagoas, bem como, os metais pesados presentes nos sedimentos. Amostras de elutriato foram preparadas em proporção 1:4 (sedimento: água). Raízes de Allium cepa foram expostas aos elutriatos obtidos dos sedimentos coletados, sendo que raízes dos grupos controle negativo e positivo foram expostas à água ultrapura e metil-metano-sulfonato, respectivamente. Após a exposição, foram analisados: comprimento das raízes, índice mitótico, aberrações cromossômicas, micronúcleos e anormalidades nucleares. $\mathrm{O} \mathrm{pH}$ de duas lagoas, e a condutividade e o nível de oxigênio dissolvido de todas as lagoas estavam abaixo do limite estabelecido pela legislação brasileira. Todas as amostras continham metais pesados e o Cd encontrava-se em nível superior ao permitido pela legislação. Raízes expostas a sedimentos das lagoas 1, 2 e 4 tiveram diminuição de crescimento. Raízes expostas ao elutriato de todas as lagoas não apresentaram alterações na divisão celular. Houve aumento significativo no número de aberrações cromossômicas em raízes expostas em todas as amostras das lagoas em comparação com ao controle negativo. Este estudo mostra que, mesmo em baixas concentrações, metais pesados podem danificar a biota, possivelmente devido a efeitos sinérgicos. Pode ser indicado que o ensaio em Allium cepa é uma ferramenta simples e útil para análises de genotoxicidade/mutagenicidade, assim como pode ser recomendado seu uso em projetos de monitoramento e gestão ambiental de áreas influenciadas por atividades de mineração.

Palavras-chave: dano celular, dano genotóxico, metais tóxicos.

\section{INTRODUCTION}

The extraction and processing of coal has been among the principle economic activities in the southern state of Santa Catarina for over 100 years (Silva et al. 2011). However, landscape changes and the consequences of residual generation have caused significant damage in both aquatic and terrestrial environments (Martins Pompêo et al., 2004; Rodriguez-Iruretagoiena et al., 2015). The improper disposal of coal extraction waste results in sulfide-rich effluent combining with oxygen and water to form an abundance of sulfuric acid $\left(\mathrm{H}_{2} \mathrm{SO}_{4}\right)$ and iron compounds, generating contaminants with potential toxicity for soil, air, groundwater, surface water, and local biota (Ribeiro et al., 2013).

Coal mining and combustion also produces abundant waste rich in heavy metals such as lead, iron, copper, zinc, chromium, cadmium, manganese and arsenic, all of which are deposited in the soil and sediment. These compounds can cause metabolic changes in local biota, and may cause harmful DNA modifications that lead to irreversible mutagenic damage (Leonard et al., 2004; Alimba et al., 2016). Fertility disorders and cellular/metabolic abnormalities are among the potential lethal and sub-lethal effects resulting from the presence of complex mixtures in water (Villela et al., 2007; Alimba et al., 2016).

Even after mining activities end, heavy metals can remain active in the environment for long periods. In this context, ecotoxicological analyses may assist in monitoring sites influenced by these activities via detection of possible toxic effects of environmental contamination on nearby organisms. Among the available assays, the Allium cepa Linnaeus (Asparaginales, Alliaceae) bioassay stands out due to its simplicity and high sensitivity in 
predicting chemically induced toxic and mutagenic effects upon organisms (source). This assay constitutes an important alternative for monitoring programs and evaluation of environmental contamination (Grant, 1982; Fiskesjö, 1985; Leme and Marin-Morales, 2009; Khanna and Sharma, 2013). This study employs the Allium серa L. bioassay to evaluate the toxicity and mutagenicity of sediment in ponds influenced by coalmining activities in Santa Catarina, southern Brazil.

\section{MATERIALS AND METHODS}

\subsection{Study Area}

The study was conducted in coal mining areas in the cities of Criciúma

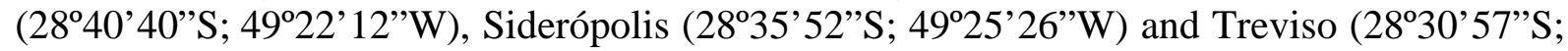
49'27'28”'W), located in the Association of Municipalities of the Coal Region (AMREC), southern Santa Catarina State, Brazil. The climate is classified as $C f a$, humid subtropical without a dry season, with average monthly temperatures between 12 and $25.9^{\circ} \mathrm{C}$ (Peel et al., 2007). Rainfall in the region ranges from $1220-1660 \mathrm{~mm}$ with total days of annual rainfall ranging from 102 to 150 days (source). Relative humidity averages 82\% (EPAGRI, 2001). The main river system is the Mãe Luzia River, which is part of the Araranguá River Basin (EPAGRI, 2001).

The predominant type of soil in the region is cambisol (46\%), with others such as kitholic neosols, gleysols, argilosol and alisols occurring in smaller percentages (EPAGRI, 2001). The geology of the area consists of Palermo, Irati, Serra Geral and Rio Bonito formations.

The locations are within the Atlantic Forest biome. Originally, the predominant vegetation type in the study area was dense sub montane rain forest. Currently, due to agro-pastoral activities, urban/industrial occupation and coal extraction, the only remaining forest fragments are in different successional stages, surrounded by grazing fields, areas devoid of vegetation and with coal residual waste, and Eucalyptus silviculture areas (EPAGRI, 2001).

Four artificial ponds were sampled, with a distance of 700 to $23000 \mathrm{~m}$ between them (Table 1). For each pond, we determined: 1) minimum distance of areas with deposits of coal waste d; 2) margin profile: flat, slight slope or steep slope; 3) margin types: dry bare soil, dry soil with vegetation, moist soil without vegetation, moist soil with vegetation; 4) vegetation strata in the margin: herbaceous, shrubby, and arboreal; 5) percentage of vegetation cover in water layers: 0-24\%, 25 to $49 \%$, and 50 to $100 \%$ (Table 1).

Table 1. Spatial and structural characteristics of ponds located in areas of influence of extraction of coal in the south of Santa Catarina, Brazil, in November 2012.

\begin{tabular}{lcllllc}
\hline Pond & Area $\left(\mathrm{m}^{2}\right)$ & D $(\mathrm{m})$ & \multicolumn{1}{c}{ MP } & \multicolumn{1}{c}{ MT } & VE & PVC \\
\hline 1 & $2,558.00$ & 0 & fl, sl & DBS, DSV, MWV & VHE, SHR & 2 \\
2 & 591.90 & 2,000 & sl, ss & DBS, DSV, MWV, MSV & VHE, SHR, VAR & 1 \\
3 & $1,348.70$ & 0 & fl, sl, ss & DBS, DSV, MWV & VHE, SHR, VAR & 1 \\
4 & $1,553.20$ & 15 & fl, sl, ss & DSV, MWV & VHE, SHR, VAR & 1 \\
\hline
\end{tabular}

Note: $\mathrm{D}=$ minimum distance of areas with coal waste; $\mathrm{MP}=$ margin profile; $\mathrm{MT}=$ margin type; $\mathrm{VE}=$ vegetative strata at the margin; PVC = percentage of vegetation cover at water surface. Margin profile: $\mathrm{fl}=\mathrm{flat}$; $\mathrm{sl}=$ slight slope; ss = steep slope. Margin types: DBS = dry bare soil; DSV = dry soil with vegetation; MSV = moist soil without vegetation; MWV = moist soil with vegetation. Vegetation: VHE = herbaceous; SHR = shrubby; VAR = arboreal. Water surface vegetation cover: $1=0-24 \% ; 2=25-50 \% ; 3=>50 \%$. 


\subsection{Water and sediment collection}

We collected three samples of water and sediment from each pond in November 2012. Water temperature, $\mathrm{pH}$, dissolved oxygen content (DO), electrical conductivity, and turbidity were measured. The parameters analyzed followed CONAMA Resolution 357/2005 for Class 2 surface water (CONAMA, 2005). Approximately $2 \mathrm{~kg}$ of sediment was collected per sample using a Petersen-type stainless steel dredge. After collection, the samples were placed in plastic bags and transported in low-temperature coolers to the Environmental Technology Laboratory at the Universidade Comunitária da Região de Chapecó, then stored at $-18^{\circ} \mathrm{C}$. Samples were analyzed for presence of iron (Fe), copper (Cu), zinc ( $\mathrm{Zn})$, manganese (Mn), cadmium (Cd) and chromium (Cr) using atomic absorption spectrophotometry. All chemical tests were performed according to Standard Methods for the Examination of Water and Waste water (APHA, 1998).

\subsection{Preparation of elutriate and analysis of sediment toxicity}

Sediment elutriate for the A. cepa test was prepared at a ratio of 1:4 sediment/water. The slurries were stirred for $60 \mathrm{~min}$. then allowed to stand for $12 \mathrm{~h}$ under refrigeration. Slurries were then centrifuged at $3000 \mathrm{rpm}$ for 5 min to obtain the supernatant, which is the elutriate (USEPA, 1998).

The A. cepa assay was performed according to Grant (1982). Six treatments were used (4 experimental samples +2 controls) with 5 replicates each. Each treatment consisted of $5 \mathrm{~A}$. cepa (onion) bulbs, each approximately $15 \mathrm{~cm}$ in circumference and with external cataphyll and aged roots removed. One bulb was placed in $50 \mathrm{ml}$ of elutriate from each sample point with the root submerged for $96 \mathrm{~h}$ in a growth chamber at $20^{\circ} \mathrm{C}$; ultrapure water was used as a negative control and $10 \mathrm{mg} \mathrm{L}^{-1}$ methyl methane sulfonate was used as a positive control. At the end of exposure, the emitted roots were measured with the aid of a millimeter ruler, fixed in methanol: acetic acid (3:1) and stored in refrigerator. Root morphology was evaluated considering coloring, folding and absence/presence of tumors.

Slides were prepared by placing two roots from each bulb over a beaker and adding two drops each of acetic acid solution (45\%) and $1 \mathrm{M} \mathrm{HCl}$ (9: 1), then heating in a water bath for 5 minutes at $50^{\circ} \mathrm{C}$ (Fiskesjö, 1985). The roots were then transferred to a slide and the hood (apical portion of the root, $\sim 1$ to $2 \mathrm{~mm}$ in length) was removed from the remaining root and discarded. Two drops of acetic orcein $2 \%$ were added to the preparation, and left to stain for five minutes. A cover slip was then placed over the root and the preparation pressed with the thumb for microscopic observation.

Two thousand cells per slide were evaluated for mitotic index (MI), total chromosomal aberrations (AC) and the presence of micronuclei (MN). The MI corresponded to the percentage of cells in the different stages of division (prophase, metaphase, anaphase and telophase). Several types of chromosomal aberrations were considered, including deletions, fragments, bridges, delays, and adherence, among others, at different stages of division. The nuclear abnormalities considered were changes in interphase nuclei, lobulated nuclei, nuclear buds, polynuclear cells, mini-cells, and interphase bridges, among others. The micronucleus analysis was performed by observing interphase micronuclei at the different stages of cell division (Leme and Marin-Morales, 2009).

\subsection{Data analysis}

Data were expressed as mean and standard error. Mean values were compared using ANOVA with a Tukey post-hoc test in GraphPadPrism version 6. Results were considered significant at $\mathrm{p} \leq 0.05$. 


\section{RESULTS AND DISCUSSION}

Pond pH values ranged from 3.86 to 6.43 (Table 2). The lowest values (3.86 and 5.81) are below the limits established by CONAMA Resolution 357/05 (CONAMA, 2005), which considers 6 to 9 normal for Class 2 rivers. Electrical conductivity values ranged from 31.8 to $73.0 \mathrm{~S} / \mathrm{cm}^{-1}$ and remained below the limit for natural waters (normal range 100 to $200 \mathrm{~S} / \mathrm{cm}^{1}$ ) (Table 1; CONAMA, 2005). Dissolved oxygen values from all samples were below the limit of 5 mg/L (Table 1; CONAMA, 2005).

Table 2. Physical and chemical characteristics of ponds in areas influenced by coal mining in the southern region of Santa Catarina, Brazil in November 2012.

\begin{tabular}{cccccc}
\hline Sample Pond & $\mathrm{pH}$ & $\begin{array}{c}\text { Electrical } \\
\text { Conductivity }(\mu \mathrm{S} / \mathrm{cm})\end{array}$ & Temperature $\left({ }^{\circ} \mathrm{C}\right)$ & Turbidity(UNT) & $\begin{array}{c}\text { DO } \\
(\mathrm{mg} / \mathrm{L})\end{array}$ \\
\hline 1 & 3.86 & 73.00 & 26.40 & 0.71 & 3.77 \\
2 & 5.81 & 60.00 & 26.00 & 16.03 & 4.26 \\
3 & 6.38 & 32.60 & 20.10 & 0.64 & 3.82 \\
4 & 6.43 & 31.80 & 19.50 & 2.83 & 4.48 \\
\hline
\end{tabular}

All heavy metals analyzed were detected in all samples (Table 3). Cd concentration was above the maximum limit established by CONAMA Resolution 344/04 (CONAMA, 2004) in all ponds. There are no legislative standards set for manganese and iron concentration in sediment. Despite the fact that $\mathrm{Cu}, \mathrm{Zn}$ and $\mathrm{Cr}$ concentration are within the limits established by law, the problem remains that in lentic waters, heavy metals have potential for bioaccumulation in living organisms (Kwok et al., 2014). Even after the source of pollution has been eliminated, accumulation of contaminants can continue to cause problems due to the release of pollutants over a long period of time (Salomons et al., 1987).

Table 3. Concentration of heavy metals in sediment in ponds affected by coal extraction in the south of Santa Catarina, Brazil in November 2012.

\begin{tabular}{ccccccc}
\hline & $\begin{array}{c}\mathrm{Cu} \\
\left(\mathrm{mg} \mathrm{kg}^{-1}\right)\end{array}$ & $\begin{array}{c}\mathrm{Cd} \\
\left(\mathrm{mg} \mathrm{kg}^{-1}\right)\end{array}$ & $\begin{array}{c}\mathrm{Mn} \\
\left(\mathrm{mg} \mathrm{kg}^{-1}\right)\end{array}$ & $\begin{array}{c}\mathrm{Zn} \\
\left(\mathrm{mg} \mathrm{kg}^{-1}\right)\end{array}$ & $\begin{array}{c}\mathrm{Fe} \\
\left(\mathrm{mg} \mathrm{kg}^{-1}\right)\end{array}$ & $\begin{array}{c}\mathrm{Cr} \\
\left(\mathrm{mg} \mathrm{kg}^{-1}\right)\end{array}$ \\
\hline Ponds & & & & & & \\
1 & 31.60 & 5.55 & 659.67 & 28.38 & $75,990.00$ & 20.57 \\
2 & 25.72 & 7.23 & 241.83 & 42.67 & $72,795.00$ & 21.23 \\
3 & 31.78 & 17.18 & 396.50 & 21.52 & $274,415.00$ & 22.63 \\
4 & 24.23 & 17.73 & 21.25 & $9,120.00$ & $41,670.00$ & 15.50 \\
$\begin{array}{c}\text { Limits established by } \\
\text { CONAMA 344/04 }\end{array}$ & 35.70 & 0.60 & - & 123.00 & - & 37.30 \\
\hline
\end{tabular}

Exposure to sediment elutriate from Ponds 1, 2 and 4 caused a reduction in the average length of $A$. cepa roots compared to the negative control, indicating toxic potential in these sediments (Figure 1). Inhibition of plant root growth is considered an indication of toxicity, since it may result from a given frequency of inhibition of cellular division (Fiskesjö, 1985; Odeigah et al., 1997; Egito et al., 2007). Such inhibition may be due to the presence of heavy metals found in the sediment, such as Zn, Cu, Mn, Fe, Cd and Cr (Fiskesjö, 1983; Lerda, 1992; Akinboro and Bakare, 2007).

Some roots tips were brownish. According Fiskesjö (1985), root tips and whole plants can change color during the test, and the brownish tinge may be related to potential toxic effects, 
causing cell death. Furthermore, some roots had a twisted and folded appearance. Fiskesjö (1985; 1988) indicated that folded roots or root tips can occur following treatment with certain metal salts, such as Cd. Some roots had tumors, which can be explained by an increase in mitotic index resulting in increased cell division, leading to uncontrolled cell proliferation and the formation of tumor tissues (Leme and Marin-Morales, 2009). Tumors were observed mainly in plants grown in elutriate from Pond 1, which had a slightly higher mitotic index.

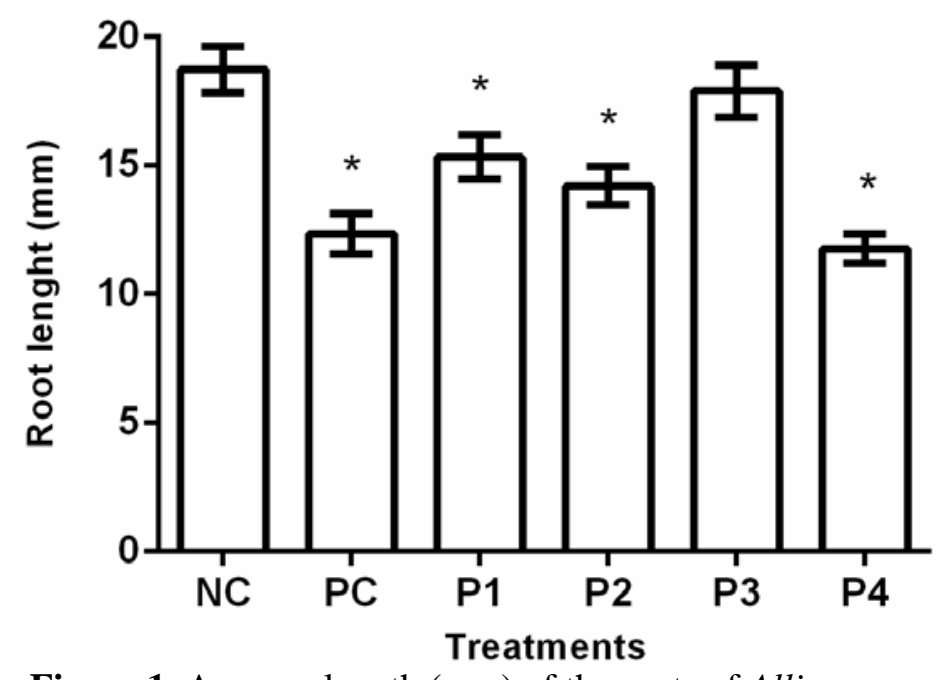

Figure 1. Average length (mm) of the roots of Allium cepa grown in sediment elutriate from ponds affected by coal mining in the southern region of Santa Catarina, Brazil in November 2012. CN: Negative control, CP: Positive control. P1: Point 1; P2: Point 2; P3: Point 3; P4: Point 4. * Statistical difference compared to the negative control $(\mathrm{p} \leq 0.05)$.

The analysis of meristematic cells in A. cepa root tips showed significant changes in cell division such as MI, CA e MN (Figure 2, Table 4).

Pond elutriates and negative control did not differ in mitotic index. However, our results showed increased CA levels. Our data are in accordance with previous studies. Similar results were reported by Rambo et al. (2017), who evaluated the toxicity of sediments from artificial reservoirs located at Upper Rio Uruguay Basin, and also did not find alterations in MI.

Genotoxic and mutagenic parameter tests indicated a significant increase in total chromosomal aberrations in A. cepa grown in elutriates from Ponds 1, 2, 3 and 4 compared with the negative ontrol group (test input values and w). Pond 4 showed a higher number of aberrations compared to the others, and Pond 2 had the lowest genotoxic potential. These results may be associated with the presence of metals in the environment, since the Cd levels were high and may have influenced the genotoxic potential in the ponds. López et al. (2010) and Lee et al. (2015) suggest that effluent from coal mine acid drainage (DAM) typically have low $\mathrm{pH}$ and high concentrations of metals and sulfates, and thus present pronounced effects of toxicity in biomarkers such as A. сера. Although some sediment metals $(\mathrm{Cu}, \mathrm{Mn}, \mathrm{Zn}, \mathrm{Fe}, \mathrm{Cr})$ were within the limits established by law (i.e., at lower concentrations), it is worth noting that the synergistic effect of these metals can cause cytotoxic, genotoxic, and mutagenic damage to exposed biota (Vargas et al., 2001). 

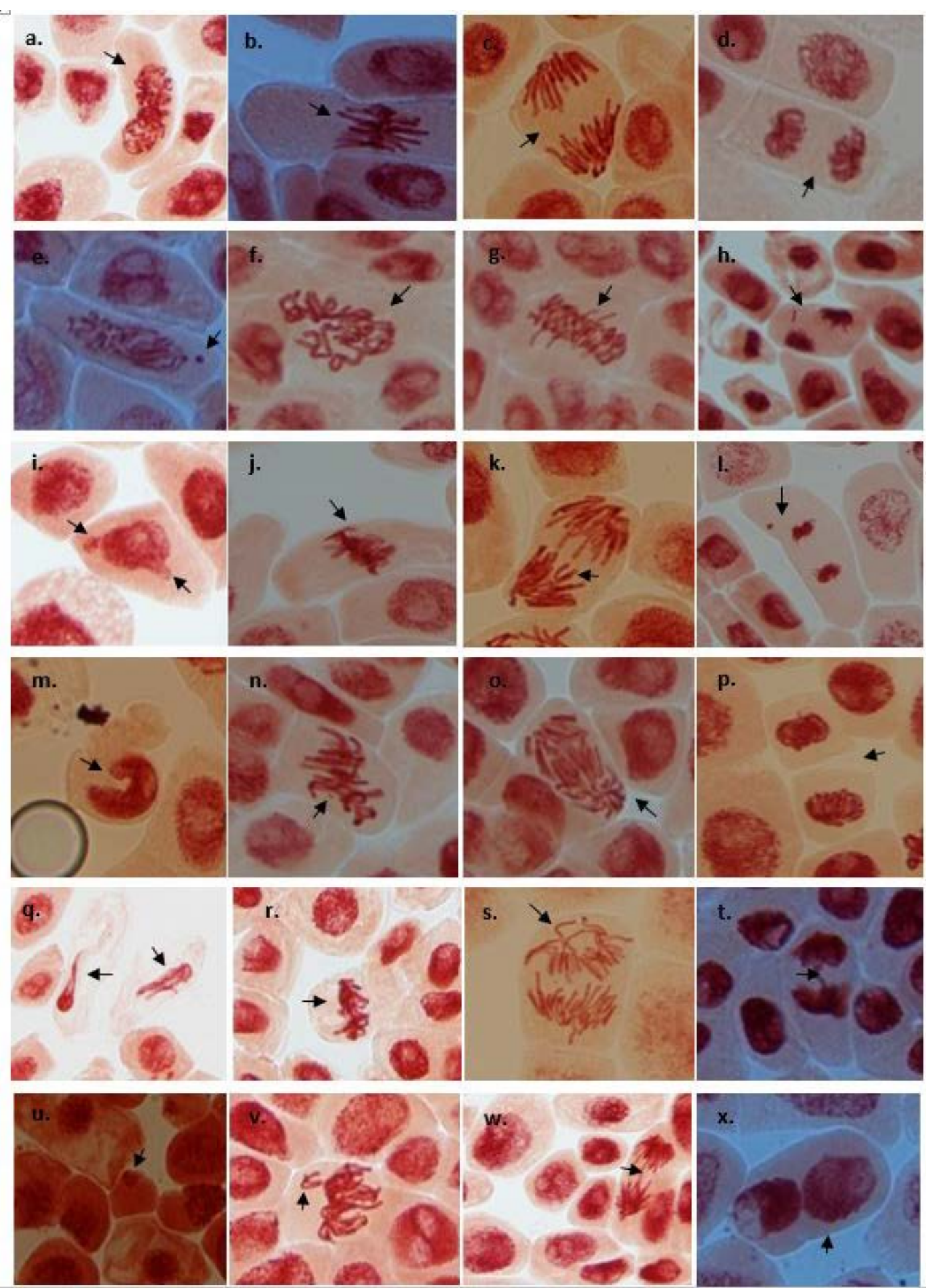

Figure 2. Allium cepa roots treated with sediment elutriate from ponds affected by coal mining in the southern region of Santa Catarina, Brazil in November, 2012 (1000X magnification).

Note: a. Normal prophase; b. Normal metaphase; c. Normal anaphase; d. Normal telophase; e. Prophase with micronucleus; f. Delayed metaphase; g. Early anaphase; h. Telophase with dispersed chromosome; i. Cellular budding; j. Sticky metaphase; k. Anaphase with lagging chromosome; l. Telophase with micronucleus; $\mathrm{m}$. Cell with lobulated nucleus; n. Metaphase with breaks; 0 . Multipolar anaphase; p. Late telophase; q. Cells with irregular nuclei; r. Metaphase with adhered chromosomes; s. Disorganized anaphase; t. Telophase bridge formation; u. Minicells; v. Metaphase with dispersed chromosome; w. Anaphase bridge formation; x. Binucleated cell. 
Table 4. Mitotic Index (MI), CA and MN in Allium cepa meristematic cells (mean \pm S.E.) after treatment with sediment elutriates from ponds impacted by coal mining in southern Santa Catarina State, Brazil.

\begin{tabular}{lccc}
\hline & MI & CA & MN \\
\hline NC & $8.21 \pm 1.60$ & $17.00 \pm 2.51$ & $0.30 \pm 0.21$ \\
PC & $5.38 \pm 0.54$ & $33.67 \pm 3.07^{*}$ & $33.14 \pm 8.33^{*}$ \\
1 & $10.56 \pm 1.37$ & $34.50 \pm 4.32^{*}$ & $0.55 \pm 0.33$ \\
2 & $9.03 \pm 1.36$ & $29.00 \pm 2.67^{*}$ & $0.55 \pm 0.44$ \\
3 & $8.22 \pm 0.77$ & $31.86 \pm 1.71^{*}$ & $0.55 \pm 0.33$ \\
4 & $9.28 \pm 0.90$ & $35.50 \pm 1.83^{*}$ & $0.66 \pm 0.23$ \\
\hline
\end{tabular}

$\mathrm{NC}=$ Negative control. $\mathrm{PC}=$ Positive control. $\mathrm{MI}=$ Mitotic Index (\%). CA = Chromosome Aberration. $\mathrm{MN}=$ Micronucleus.

*Statistically different from the control at $\mathrm{p}<0.05$.

Chromosome bridges and breaks are indicators of a clastogenic action, while chromosme loss, delay, adhesion, multipolarity and C-metaphases result from aneugenic effects (Leme and Marin-Morales, 2009). The occurrence of aberrations in the mitotic stage may result from toxicity of the achromatic spindle fibers (Chandra et al., 2005). Matsumoto and Marin-Morales (2004) assessed the mutagenic potential of water samples from a river that receives effluent from an industrial tannery and observed a high rate of chromosomal aberrations, most likely due to the presence of chromium residuals derived from this activity.

Adhered chromosomes were also observed in studies by Smaka-Kincl et al. (1996) and Marcano et al. (2004). This phenomenon has been reported to be indicative of high toxicity with irreversible effects that may lead to cell death (Fiskesjö, 1985; Marcano et al., 1998). When evaluating different metal ions (Hg, Cu, Ni, Cd, Be, Al, Cr, Mn, Li), Fiskesjö (1988) also found aberrations such as C-metaphases, sticky chromosomes and bridges in different mitotic divisions, among others. This information confirms that metal can produce genotoxic effects upon exposed biota, and that $\mathrm{Cu}$ at high concentrations is lethal to A. cepa cells, and such aberrations were also found in this study. Barbério et al. (2009) also found significant genotoxic effects in a study of the Paraíba do Sul River, and micronuclei, chromosome bridges, c-mitosis, multipolar anaphase, other chromosomal aberrations and total number of abnormal cells showed a significant increase over the negative control group.

According to Fungaro and Izidoro (2006), DAM contains dissolved metal ions, where composition and concentration depends on specific geological conditions. Campaner et al. (2014), in a multi-element chemical analysis conducted on DAM water samples, found that it presents typical metals such as Fe, Mn, Zn, Al, Cd, Co, Ni near active mines and waste deposits in the proximity of disabled mines.

No differences were observed in the nuclear abnormalities between pond samples analyzed. However, despite no significant difference in NA incidence, different abnormalities were observed, among them nuclear budding, irregular nuclei, interphase bridges, minicells, lobed nuclei and binucleated cells (Figure 2). Nuclear abnormalities are characterized by morphological changes in interphase nuclei in response to the action of some tested agent (Leme and Marin-Morales, 2009). According to Fernandes et al. (2007), nuclear buds are likely to be caused by polyploidization events in which the excess genetic material is removed from the cells. The presence of multinucleated cells and lobulated nuclei may indicate processes of cell death. Irregular nuclei are characterized by altered morphology and size, appearing before the formation of nuclear buds. Rambo et al. (2015) states there is a possible sequence of events 
driving abnormalities, starting with the presence of irregular nuclei and followed by bud formation until elimination or as micronuclei or as minicells. Binucleated cells arise because of inhibition of cell plate formation. Mitotic irregularities such as incomplete anaphase or unequal distribution of chromosomes to daughter cells can lead to aneuploid, or even euploid cells (Grant, 1978).

There were also no significant differences in the analysis of micronuclei between the ponds studied. According Fenech et al. (2011) the MN are sourced from chromosome fragments or whole chromosomes during cell division, which can be seen in the cytoplasm of the daughter cells as small additional cores near the main core. The MN can form spontaneously, or in response to the action of certain agents (clastogenic or aneugenic) (Ceppi et al., 2010). In the present study, we observed micronuclei in cell division phases as well as micro-nucleated cells, probably resulting from multiple breaks and fragments, indicating clastogenic effects, also found micronuclei of large size, indicating aneugenic effects (Fenech, 2002).

In studies evaluating the genotoxic effects of heavy metals, Steinkellner et al. (1998) showed positive results of $\mathrm{As}, \mathrm{Pb}, \mathrm{Cd}$ and $\mathrm{Zn}$ on $\mathrm{A}$. cepa cells in the MN test. Matsumoto et al. (2006) also showed significant frequency of AC and MN in A. cepa meristematic cells after exposure to river water samples contaminated with $\mathrm{Cr}$ ions due to a nearby tannery. However, the individual analysis of micronuclei is not always a sufficiently sensitive parameter for quantification of genotoxic potential. Thus, integrated analyses (e.g., evaluating chromosomal aberrations and nuclear abnormalities) may better evaluate damage in tested samples (Rambo et al., 2015).

The impact of coal mining on biota residing in affected areas may persist for years after activities halt, because heavy metals can remain active in the environment for a long period. Among the harmful effects to organisms, they are highly toxic, have the capacity for bioaccumulation, and are capable of causing damage to genetic material and producing genotoxic and mutagenic effects. In this study, we highlight that even at low concentrations heavy metals can cause damage to exposed biota, possible due to synergistic effect. The A. cepa bioassay proved a useful tool for analyses of this nature, especially for the evaluation of cytotoxic and genotoxic effects on the environment generated by the extraction and processing of coal. Bioassays such as this may be used in environmental monitoring and management, as well as in programs for environmental restoration, and monitoring of ground and surface water in areas degraded by mining.

\section{CONCLUSIONS}

Our studies showed that $A$. сера bioassay is a simple and useful tool for genotoxicity/mutagenicity analyses for use in environmental monitoring and management in areas influenced by mining activities. We concluded that the analysis of the water is an essential phase for screening mining areas potentially contaminated by genotoxic chemical compounds.

The distribution of genotoxicity in the four ponds studied illustrates the complexity of the study of regions exposed to multiple pollutants; even low concentrations of heavy metals can damage exposed biota, possibly due to synergistic effects. Although the identification of areas contaminated by genotoxic agents using $A$. cepa assay represents an important step of environmental diagnosis, the identification of the classes of chemical compounds present necessary to determine appropriation remediation in the ponds affected.

\section{ACKNOWLEDGEMENTS}

We thank the "Fundo de Apoio à Manutenção e ao Desenvolvimento da Educação Superior (FUMDES)” fellowship program for financial support.

\section{IPABH}

Rev. Ambient. Água vol. 12 n. 4 Taubaté - Jul. / Aug. 2017 


\section{REFERENCES}

AKINBORO, A.; BAKARE, A. A. Cytotoxic and genotoxic effects of aqueous extracts of five medicinal plants on Allium cepa Linn. Journal of Ethnopharmacology, v. 112, p. 470475, 2007. https://doi.org/10.1016/j.jep.2007.04.014

ALIMBA, C. G.; DHILLON, V.; BAKARE, A. A.; FENECH, M. Genotoxicity and cytotoxicity of chromium, copper, manganese and lead, and their mixture in WIL2-NS human B lymphoblastoid cells is enhanced by folate depletion. Mutation Research/Genetic Toxicology and Environmental Mutagenesis, v. 798-799, n. 1, p. 3547, 2016. https://doi.org/10.1016/j.mrgentox.2016.02.002

AMERICAN PUBLIC HEALTH ASSOCIATION - APHA. Standard Methods for the Examination of Water and Waste Water. 20th Edition. Washington DC, 1998.

BARBÉRIO, A.; BARROS, L.; VOLTOLINI, J. C.; MELLO, M. L. S. Evaluation of the cytotoxic and genotoxic potential of water from the River Paraíba do Sul, in Brazil, with the Allium cepa L. test. Brazilian Journal of Biology, v. 69, n. 3, p. 837-842, 2009. http://dx.doi.org/10.1590/S1519-69842009000400010

CAMPANER, V. P.; LUIZ-SILVA, W.; MACHADO, W. Geochemistry of acid mine drainage from a coal mining area and processes controlling metal attenuation in stream waters, southern. Anais da Academia Brasileira de Ciências, v. 86, n. 2, p. 539-554, 2014. http://dx.doi.org/10.1590/0001-37652014113712

CEPPI, M.; BIASOTTI, B.; FENECH, M.; BONASSI, S. Human population studies with the exfoliated buccal micronucleus assay: statistical and epidemiological issues. Mutation Research/Reviews in Mutation Research, v. 705, n. 1, p. 11-19, 2010. https://doi.org/10.1016/j.mrrev.2009.11.001

CHANDRA, S.; CHAUHAN, L. K.; MURTHY, R. C.; SAXENA, P. N.; PANDE, P. N.; GUPTA, S. K. Comparative biomonitoring of leachates from hazardous solid waste of two industries using Allium test. Science of The Total Environment, v. 347, n. 1-3, p. 46-52, 2005. https://doi.org/10.1016/j.scitotenv.2005.01.002

CONSELHO NACIONAL DO MEIO AMBIENTE - CONAMA (Brasil). Resolução n 344, de 25 de março de 2004. Estabelece as diretrizes gerais e os procedimentos mínimos para a avaliação do material a ser dragado em águas jurisdicionais brasileiras, e dá outras providências. 2004. Available in: http://www.mma.gov.br/port/conama/legiabre.cfm? codlegi=445 . Access in: Aug. 2016.

CONSELHO NACIONAL DO MEIO AMBIENTE - CONAMA (Brasil). Resolução n 357, de 17 de março de 2005. Dispõe sobre a classificação dos corpos de água e diretrizes ambientais para o seu enquadramento, bem como estabelece as condições e padrões de lançamento de efluentes, e dá outras providências. 2005. Available in: http://www. mma.gov.br/port/conama/res/res05/res35705.pdf. Access in: Aug. 2016.

EGITO, L. C. M.; MEDEIROS, M. G.; MEDEIROS, S. R. B.; AGNEZ-LIMA, L. F. Cytotoxic and genotoxic potential of surface water from the Pitimbu River, northeastern/RN Brazil. Genetics and Molecular Biology, v. 30, n.2, p. 435-441, 2007. http://dx.doi.org/10.1590/S1415-47572007000300023 
EMPRESA DE PESQUISAS AGROPECUÁRIA E DE EXTENSÃO RURAL DE SANTA CATARINA - EPAGRI. Dados e informações bibliográficas da Unidade de Planejamento Regional Litoral Sul Catarinense - UPR 8. Florianópolis, 2001.

FENECH, M. Biomarkers of genetic damage for cancer epidemiology. Toxicology, v. 181-182, p. 411-416, 2002. https://doi.org/10.1016/S0300-483X(02)00480-8

FENECH, M.; KIRSCH-VOLDERS, M.; NATARAJAN, A. T.; SURRALLES, J.; CROTT, J. W.; PARRY, J. et al. Molecular mechanisms of micronucleus, nucleoplasmic bridge and nuclear bud formations in mammalian and human cells. Mutagenesis, v. 26, n. 1, p. 125132, 2011. https://doi.org/10.1093/mutage/geq052

FERNANDES, T. C. C.; MAZZEO, D. E. C.; MARIN-MORALES, M. A. Mechanism of micronuclei formation in polyploidizated cells of Allium cepa exposed to trifluralin herbicide. Pesticide Biochemistry and Physiology, v. 88, p. 252-259, 2007. https://doi.org/10.1016/j.pestbp.2006.12.003

FISKESJÖ, G. Nucleolar dissolution induced by aluminum in root cells of Allium. Physiologia Plantarum, v. 59, n. 3, p. 508-511, 1983. http://dx.doi.org/10.1111/j.1399-3054. 1983.tb04238.x

FISKESJÖ, G. The Allium test as a standard in environmental monitoring. Hereditas, v. 102, n. 1, p. 99-112, 1985. http://dx.doi.org/10.1111/j.1601-5223.1985.tb00471.x

FISKESJÖ, G. The Allium test - an alternative in environmental studies: the relative toxicity of metal ions. Mutation Research/Fundamental and Molecular Mechanisms of Mutagenesis, v. 197, n. 2, p. 243-260, 1988. https://doi.org/10.1016/0027-5107 (88)90096-6

FUNGARO, D. A.; IZIDORO, J. C. Remediação de Drenagem Ácida de Mina Usando Zeólitas Sintetizadas a Partir de Cinzas Leves de Carvão. Química Nova, v. 29, n. 4, p. 735-740, 2006. http://dx.doi.org/10.1590/S0100-40422006000400019

GRANT, W. F. Chromosome Aberrations in Plants as a Monitoring System. Environmental Health Perspectives, v. 27, p. 37-43, 1978. https://dx.doi.org/10.2307/3428860

GRANT, W. F. Chromosome aberration assays in Allium: a report of the U.S. environmental protection agency Gene-Tox program. Mutation Research/Reviews in Genetic Toxicology, v. 99, n. 3, p. 273-291, 1982. https://doi.org/10.1016/0165-1110(82)90046$\mathrm{X}$

KHANNA, N.; SHARMA, S. Allium Cepa Root Chromosomal Aberration Assay: A Review. Indian Journal of Pharmaceutical \& Biological Research, v. 1, p. 105-119, 2013. http://imsear.hellis.org/handle/123456789/157242

KWOK, C. K.; LIANG, Y.; WANG, H.; DONG, Y. H.; LEUNG, S. Y.; WONG, M. H. Bioaccumulation of heavy metals in fish and Ardeid at Pearl River Estuary, China. Ecotoxicology and Environmental Safety, v. 10, p.62-67, 2014. https://doi.org/10.1016/j.ecoenv.2014.04.016

LEE, S.-H.; KIM, I.; KIM, K.-W.; LEE, B.-T. Ecological assessment of coal mine and metal mine drainage in South Korea using Daphnia magna bioassay. SpringerPlus, v. 4, p. 518, 2015. https://dx.doi.org/10.1186\%2Fs40064-015-1311-1 
LEME, D. M.; MARIN-MORALES, M. A. Allium cepa test in environmental monitoring: A review on its application. Mutation Research/Reviews in Mutation Research, v. 682, n. 1, p. 71-81, 2009. https://doi.org/10.1016/j.mrrev.2009.06.002

LEONARD, S. S.; BOWER, J. J.; SHI, X. Metal-induced toxicity, carcinogenesis, mechanisms and cellular responses. Molecular and Cellular Biochemistry, v. 255, n. 1, p. 3-10, 2004. https://dx.doi.org/10.1023/B:MCBI.0000007255.72746.a6

LERDA, D. The effect of lead on Allium cepa L. Mutation Research Letters, v. 281, n. 2, p. 89-92, 1992. https://doi.org/10.1016/0165-7992(92)90041-F

LÓPEZ, D. L.; GIERLOWSKI-KORDESCH, E.; HOLLENKAMP, C. Geochemical mobility and bioavailability of heavy metals in a lake affected by acid mine drainage: Lake Hope, Vinton County, Ohio. Water, Air, and Soil Pollution, v. 213, p. 27-45, 2010. https://dx.doi.org/10.1007/s11270-010-0364-6

MARCANO, L.; MONTIEL, X.; CARRUYO, I.; BRACHO, M. D. P.; ATENCIO, L. Efecto mitotóxico y genotóxico del cadmio en células meristemáticas de cebolla (Allium cepa L.). Ciência, v. 6, n. 2, p. 93-99, 1998.

MARCANO, L.; CARRUYO, I.; DEL CAMPO, A.; MONTIEL, X. Cytotoxicity and mode of action of maleic hydrazide in root tips of Allium сера L. Environmental Research, v. 94, n. 2, p. 221-226, 2004. https://doi.org/10.1016/S0013-9351(03)00121-X

MARTINS POMPÊO, M. L.; MOSCHINI-CARLOS, V.; ALEXANDRE, N. Z.; SANTO, E. Water quality in disturbed area by coal mining, Fiorita River basin (Siderópolis, State of Santa Catarina, southern Brazil). Acta Scientiarum - Biological Sciences, v. 26, p. 125136, 2004. https://dx.doi.org/10.1111/j.1601-5223.1997.00161.x

MATSUMOTO, S. T, MARIN-MORALES M. A. Mutagenic potential of the water of a river that receives tannery effluent using the Allium cepa test system. Cytologia, v. 69, n. 4, p. 399-408, 2004. https://www.jstage.jst.go.jp/pub/images/icon_article_doi.png

MATSUMOTO, S. T.; MANTOVANI, M. S.; MALAGUTTII, M. I. A.; DIAS, A. L.; FONSECA, I. C.; MARIN-MORALES, M. A. Genotoxicity and mutagenicity of water contaminated with tannery effluents, as evaluated by the micronucleus test and comet assay using the fish Oreochromis niloticus and chromosome aberrations in onion roottips. Genetics and Molecular Biology, v.29, n.1, p. 148-158, 2006. http://dx.doi.org/ 10.1590/S1415-47572006000100028

MAZZEO, D. E.; MARIN-MORALES, M. A. Genotoxicity evaluation of environmental pollutants using analysis of nucleolar alterations. Environmental Science and Pollution Research, v. 22, n. 13, p.9796-806, 2015. https://dx.doi.org/10.1007/s11356-015-41342

ODEIGAH, P. G. C.; NURUDEEN, O.; AMUND, O. O. Genotoxicity of oil field wastewater in Nigeria. Hereditas, v. 126, n. 2, p. 161-167, 1997. https://dx.doi.org/10.1111/j.16015223.1997.00161.x

PEEL M. C.; FINLAYSON, B. L.; MCMAHON, T. A. Updated world map of the KoppenGeiger climate classification. Australia. Hydrology and Earth System Sciences, v. 11, n. 5, p. 1633-1644, 2007. 
RAMBO, C. L.; ZANOTELLI, P.; NEZ, D.; SZCZEPANIK, J.; ROSEMBERG, D. B.; CARASEK, F. et al. Avaliação da toxicidade e mutagenicidade dos sedimentos da Usina Hidrelétrica Foz do Chapecó utilizando o sistema teste Allium cepa. In: DAL MAGRO, M. L.; RENK, A.; FRANCO, G. M. de S. Impactos socioambientais da implantação da Hidrelétrica Foz do Chapecó. Chapecó: Argos, 2015. p. 369-394.

RAMBO, C. L.; ZANOTELLI, P.; DALEGRAVE, D.; DE NEZ, D.; SZCZEPANIK, J.; CARAZEK, F. et al. Hydropower reservoirs: cytotoxic and genotoxic assessment using the Allium cepa root model. Environmental Science and Pollution Research, v. 24, p. 8759-8768, 2017. https://doi.org/10.1007/s11356-017-8509-4

RIBEIRO, J.; TAFFAREL, S. R.; SAMPAIO, C. H.; FLORES, D.; SILVA, L. F. O. Mineral speciation and fate of some hazardous contaminants in coal waste pile from anthracite mining in Portugal. International Journal of Coal Geology, v. 109-110, p. 15-23, 2013. https://doi.org/10.1016/j.coal.2013.01.007

RODRIGUEZ-IRURETAGOIENA, A.; FDEZ-ORTIZ DE VALLEJUELO, S.; GREDILLA, A.; RAMOS, C. G.; OLIVEIRA, M. L. S.; ARANA, G. et al. Fate of hazardous elements in agricultural soils surrounding a coal power plant complex from Santa Catarina (Brazil). Science of the Total Environment v. 508, p. 374-382, 2015. https://doi.org/10. 1016/j.scitotenv.2014.12.015

SALOMONS W.; ROOIJ, N. M. DE; KERDIJK, H.; BRIL, J. Sediments as a source for contaminants? Hydrobiologia, v. 149, n. 1, p. 13-30, 1987. https://dx.doi .org/10.1007/BF00048643

SILVA, L. F. O.; WOLLENSCHLAGER, M.; OLIVEIRA, M. L. S. A preliminary study of coal mining drainage and environmental health in the Santa Catarina region, Brazil. Environmental Geochemistry and Health, v. 33, n. 1, p. 55-65, 2011. https://dx.doi.org/10.1007/s10653-010-9322-X

SMAKA-KINCL V.; STEGNAR, P.; LOVKA, M.; TOMAN, M. J. The evaluation of waste, surface and ground water quality using the Allium test procedure. Mutation Research/Genetic Toxicology, v. 368, n. 3-4, p. 171-179, 1996. https://doi.org/10.1016/S0165-1218(96)90059-2

STEINKELLNER, H.; MUN-SIK, K.; HELMA, C.; ECKHER, S.; MA, T. H.; HORAK, O.; KUNDI, M. et al. Genotoxic effects of heavy metals: comparative investigation with plant bioassays. Environmental and Molecular Mutagenesis, v. 31, n. 2, p. 183-191, 1998. https://dx.doi.org/10.1002/(SICI)1098-2280(1998)31:2<183::AID-EM11>3.0.CO ;2-8

UNITED STATES. Environmental Protection Agency - USEPA. Great Lakes Dredged Material Testing and Evaluation Manual. Appendix F. Chicago, 1998.

VARGAS, V. M. F.; MIGLIAVACCA, S. B.; DE MELO, A. C.; HORN, R. C.; GUIDOBONO, R. R.; FERREIRA, I. C. F. DE S. et al. Genotoxicity assessment in aquatic environments under the influence of heavy metals and organic contaminants. Mutation Research/Genetic Toxicology and Environmental Mutagenesis, v. 490, n. 2, p. 141158, 2001. https://doi.org/10.1016/S1383-5718(00)00159-5 
VILLELA, I. V.; DE OLIVEIRA, I. M.; SILVEIRA, J. C.; DIAS, J. F.; HENRIQUES, J. A.; DA SILVA, J. Assessment of environmental stress by the micronucleus and comet assays on Limnoperna fortunei exposed to Guaíba hydrographic region samples (Brazil) under laboratory conditions. Mutation Research/Genetic Toxicology and Environmental Mutagenesis, v. 628, n. 2, p. 76-86, 2007. https://doi.org/10.1016/j. mrgentox.2006.12.001 